\title{
Besættelsesforskningens faser og veje
}

Den store kildeudgave om Werner Bests korrespondance, som Det Kongelige Bibliotek udgav $i$ 2012, affodte en foredragsrakke om aktuelle emner i relation til udgaven. Indledningsvist blev banen kridtet op af professor Claus Bryld med et foredrag d. 18. april om besattelsesforskningens udvikling siden 1945. Artiklen her er en bearbejdet udgave af foredraget.

afprofessor, dr.phil. Claus Bryld

Roskilde Universitetscenter

I

John T. Lauridsens store bibliografi fra 2002 over den samlede danske litteratur om besættelsestiden skriver han $\mathrm{i}$ indledningen:

"At der er skrevet meget om den danske besættelsestid er ikke ensbetydende med, at der er skrevet tilstrækkeligt, endsige at det allerede skrevne er det sidste ord i den sag. En betydelig del af litteraturen reproducerer besættelsestidens og befrielsesdagenes patriotiske toner".

Bibliografien demonstrerer disse ord i praksis. Den største gruppe af indførsler drejer sig om modstandsbevægelsen i den ene eller anden form. Også de fleste værker, der ikke direkte omhandler modstandsbevægelsen, skildrer besættelsestiden set ud fra modstandsbevægelsens synsvinkel, i hvert fald i den brede betydning af ordet modstand. Det vender jeg tilbage til om lidt.

Bibliografien rummer 7.525 indførsler, og der er senere kommet et par supplementer. Dette væld af publikationer om en kort og afgrænset periode i Danmarkshistorien er enestående. Ikke engang '1864' kan opvise et tilsvarende antal bøger og afhandlinger; om denne krig forelå der i 1990 godt 3.300 publikationer, og det vel at mærke på 126 års afstand. Man kan levende forestille sig, hvor mange ekstra indførsler Lauridsens bibliografi vil have fået om 58 år, når der er gået 126 år siden besættelsen sluttede!

Der er skrevet mere eller mindre om stort set alle politiske, økonomiske, sociale og kulturelle fænomener under besættelsen. Uden at følge John T. Lauridsens systematik kan man i flæng nævne de store kildesamlinger, der udkom lige efter krigen, samleværkerne med hele besættelsestidens historie, erindringer om besættelsestiden på alle niveauer lige fra hovedpersoner som P. Munchs, Erik Scavenius', Thune Jacobsens, Ole Bjørn Krafts, Ebbe Muncks, Frode Jakobsens, Mogens Fogs og Børge Houmanns til almindelige modstandsfolks og borgeres erindringer, øjenvidneskildringer af f.eks. 9. april eller 29. august, 'set og sket'-bøger med mange forskellige bidrag, rene billedværker, presse- og massemediehistorier, sabotør-fortællinger fra folk i forskellige modstandsgrupper, kz-lejr- og deportationshistorier, jødernes flugt, andre flygtninge, militære historier, de frie danske i udlandet, lokalhistorier, hverdagshistorier, Rigsdagen under besættelsen, samarbejdspolitikken, modstandsbevægelsen som helhed, biografier osv., osv.

Det meste af denne informationsoparbejdning og -spredning skete i bog- eller artikelform, men naturligvis også $\mathrm{i}$ dagspressen, hvis artikler ikke er medtaget 
i bibliografien, og i de nyere massemedier som radio, film og fra 1950'erne TV. Der er også udgivet tegneserier om besættelsestiden, og sammen med filmene mv. kan man altså tale om en formidling inden for både masse- og finkulturen, som man traditionelt har opdelt kulturen i. Blandt bøgerne hører også skønlitteraturen hjemme - og er medtaget i Lauridsens bibliografi. De fiktive værker - eller i hvert fald en del af dem såsom Hans Scherfigs Frydenholm og Erik Aalbæk Jensens Kridtstregen (uden sammenligning i øvrigt) har ligeledes haft betydning for den historiske diskussion og bevidstheden om besættelsestiden, en betydning, som i kraft af romanernes brede reception formentlig er større end nogen af de historiske fagbøgers som enkeltværker betragtet. Det samme gælder for filmene.

John T. Lauridsens bibliografi bliver på denne måde en kilde til det danske samfunds forståelse af besættelsestiden fra 1945 til 2002. Og en optælling af titler under de forskellige kategorier af litteratur kan give nogle indikationer på denne selvforståelse. Således er der 277 indførsler om 9. april, inklusive forspillet og de civiles oplevelser i forbindelse med besættelsen, mens der er 186 om de samarbejdende partier og 24 om centraladministrationen. Der er ganske vist 99 titler om forhandlings- og samarbejdspolitikken generelt, men $i$ hvert fald halvdelen af disse er skrevet ud fra et kritisk, ofte direkte afstandtagende, perspektiv. Modsat forholder kun nogle få af de 883 bøger om modstandsbevægelsen sig kritisk over for denne, og her er lokalhistorien ikke medtaget. De eneste ansatser til et mere distanceret syn på modstandsbevægelsen og dens forskellige aktiviteter er Aage Trommers bøger, Esben Kjeldbæks om modtandsorganisationen BOPA og Peter Birkelunds om den borgerligt-nationale modstandsbevægelse foruden Stefan Emkjærs og Peter Øvig Knudsens bøger om stikkerlikvideringerne; her ser jeg ser bort fra nogle få artikler, der forholder sig kritisk til DKP's linje ud fra et venstresocialistisk perspektiv, eller som forsøger at påvise, at Aksel Larsen i 1942 optrådte som angiver under Gestapos forhør af ham.

tandet træk, der faldt i øjnene, da
Lauridsens bibliografi udkom i
2002, var fordelingen af stof mellem besættelsestidens politisk-nationale aspekt og det økonomisk-sociale. Der var få publikationer om økonomiske og sociale forhold, og langt de fleste var skrevet umiddelbart efter eller i slutningen af besættelsen som et led i efterkrigsbearbejdelsen. Kun ganske enkelte er fra tiden efter 1960 . Om arbejdet for værnemagten figurerede kun nogle få publikationer. Om arbejdsmarkedet og dets organisationer var der 66 titler, mest bestående af afsnit i forskellige værker, men ikke nogen monografi. Tilsvarende var erhvervslivets forhold og den økonomiske kollaboration $\mathrm{i}$ landbrug og industri mistrøstigt repræsenteret. Mentalitetshistorie, f.eks. om folkestemningen, var fraværende - jeg kunne i hvert fald ikke finde den.

Et andet kvantitativt interessant moment, der indirekte belyses af bibliografien, er de 'bølger' i udgivelsesrytmen, der er. Lige efter krigen udkom der en masse litteratur af overvejende patriotisk eller harmoniserende art alt efter om det var modstandsbevægelsen eller samarbejdspolititikere, der stod bag. Især for politikernes vedkommende var der tale 
om efterrationaliserende legitimering. I tiden ca. 1950 til begyndelsen af 1970'erne skete der imidlertid et fald i udgivelser om besættelsestiden, der så igen blev fulgt af en stigning. Fra begyndelsen af 70'erne var den harmoniserende, konsensusprægede litteratur imidlertid på tilbagetog, mens den patriotiske nærmest blev alt dominerende. Og kurven gik stadig opad i 1990'erne. Det svarer interessant nok til den indholdsmæssige udvikling $i$ iscenesættelsen af befrielsesjubilæerne i 1985 og 1995, hvor især det første repræsenterede et højdepunkt af nationalpatriotisk selvdyrkelse. $^{2}$

I vores bog fra 1998, Besattelsestiden som kollektiv erindring, har Anette Warring og jeg i kort form søgt at gengive den grundfortælling eller master narrative, som det hedder på engelsk, der karakteriserer disse mange år, og som fandt udtryk i utallige udgivelser. Som eksempel brugte vi en tekst af besættelseshistoriker-nestoren Jørgen Hæstrup. Den blev leveret til et teksthæfte, der skulle bruges til studentereksamen i 1983 . Her skulle den fungere som den baggrundsorientering, eleverne kunne tage udgangspunkt $i$, hvis de ville skrive om besættelsestiden, og måtte således anses for en objektiv fremstilling, som eleverne ikke skulle bedrive fortolkningsanalyse på. Vi forsøgte at anvende narrativ medieteori på den, og vores analyse lød sådan her (og der er vel at mærke ikke forkortet i teksten):

Sætningen "Ved 2. verdenskrigs udbrud 1939 erklærede Danmark sig neutralt" udgør forspillet eller optakten til den egentlige fortælling. Herefter kommer anslaget:
"Den 9. april 1940 blev landet efter en kortvarig kamp besat af tyske tropper. Den danske regering blev stillet over for krav om, at Danmark skulle bøje sig for en tysk besættelse. Under protest og for at skåne landet for krig gik regeringen ind herpå. Mulighed for militært at forhindre besættelsen forelå ikke; hjælp udefra kunne ikke ventes".

Anslaget efterfølges af en presentation af fortællingens hovedtema:

"Indrømmelsen den 9. april blev kun begyndelsen. I årene 1940-43 gav regeringen efter for stadig nye tyske krav: Tyskerne udplyndrede landet, øvede censur og blandede sig i retsvæsenet".

Herefter følger fortællingens hoveddel og midte, bestående først af en uddybning af plottet, som er fortællingens spændingsskabende handlingskonflikt:

"I protest mod indrømmelsespolitikken voksede modstandsbevægelsen frem. Voksende kredse, ikke mindst unge, krævede, at Danmark gik i direkte kamp mod nazisterne. Der skabtes en fri illegal presse, som førte kravet herom frem. Samtidig begyndte fra 1942 en sabotage, der understregede alvoren bag kravet, og de første kontakter med den frie verden blev skabt".

Den efterfølgende tekstdel udgør fortællingens point of no return:

"I 1943 blev det åbenbart, at befolkningen ikke længere stod bag indrømmelsespolitikken. En kraftig sabotagebølge rullede over landet, ledsaget af store folkestrejker. Tyskerne stillede nye krav til regeringen, bl.a. om indførelse af dødsstraf. Regeringens svar blev et nej, og den 29. august 1943 angreb tyskerne den 
danske hær og flåde. Flåden sænkede sine skibe. Regeringen ophørte at fungere, og tyskerne overtog åbentlyst magten i landet".

Den sidste del af fortællingens hoveddel er så den fase, hvor konflikten optrappes:

"Dette standsede ikke modstandsbevægelsen. Tværtimod. Overfor den tyske tvang og terror, som nu satte ind, samledes stadig flere om kampen, og under ledelse af Danmarks Frihedsråd knyttedes grupperne sammen i en stadig større og fastere organisation i nøje kontakt med de allierede. Herved fik kampen større strategisk betydning. Materiel til kampen kom fortrinsvis udefra, fra Sverige og især fra England. Våben nedkastedes fra flyvere eller førtes over Nordsøen og Kattegat. Store organisationer arbejdede med modtagelse og fordeling af våbnene”.

Fortællingens afslutning rummer klimaks og udtoning - dog nærmest i omvendt rækkefølge - og her forloses plottets konflikt:

"Modstandsbevægelsen nåede sine mål: At føre Danmark ind i kampen mod nazismen og skaffe Danmarks kamp anerkendelse som en del af den fælles allierede kamp. Kampen krævede tunge ofre. Den tyske terror omfattede vilkårlige sprængninger af kendte danske bygninger og mord på tilfældige og uskyldige danske, og overfor modstandsfolkene omfattede den fængslinger, tortur, henrettelser og deportationer. Det blev kampens vilkår, men vilkårene knækkede ikke modstandsviljen. Flere og flere sluttede op bag modstandsbevægelsen, og skønt kampen oprindeligt blev rejst af et mindretal, var det et enigt folk, der den 4. maj 1945 kunne modtage frihedsbudskabet".

Her slutter fortællingen uden noget efterspil. $^{3}$

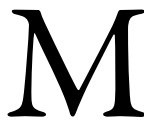
an skal ikke være faguddannet historiker for at se tendensen i denne fremstilling. Den hviler på et grundlæggende harmoniserings- eller konsensussyn, der betoner den nationale enhed og sammenholdet og tilsvarende fortier de politiske og sociale modsætninger. Der er heller ikke nogen kronologisk udvikling i den, besættelsestiden er stort set den samme fra start til slut.

Den slags formidling af historien om besættelsestiden har givetvis haft stor betydning for 'indpodningen' af nationale værdier i befolkningen og vel særlig i ungdommen siden 1945. Denne indpodning har ikke blot fundet sted i skolen, hvor den stadig finder sted - jf. historiekanonen, hvor det er 29. august 43, der skal undervises i og ikke 9. april eller 22. juni 41 - men også gennem talrige andre socialisationsagenturer som spejderkorps, militæret, ungdomsforeninger og -klubber samt ikke mindst gennem massemedierne.

Under den kolde krig havde dette en særlig betydning. Formidlingen blev ikke kun rettet mod bevidstheden, men også mod et førbevidst, følelsesmæssigt plan. Og traderingen og accepten af den sejrende version gik så meget lettere, som versionen kunne påpege alle de ugerninger, nazismen og fascismen stod faddere til. Men traderingen fik som helhed den konsekvens, også for den mere kognitive formidling - i modsætning til den mere følelsesprægede - at denne ofte blev præget af mangel på stringens og nuancering. Traditionens oprindelse i en 
militær og politisk kamp bevirkede, at der ofte i højere grad blev tale om en formidling, hvis form nærmede sig propagandaen end oplysning i klassisk forstand. Det er Hæstrups tekst et eksempel på. Når der skulle fortælles om de sider af besættelsesproblematikken, som ikke passede med den pågældende tids egen opfattelse af rigtigt og forkert, kom empatien til kort, og herved blev mange vigtige indsigter blokeret. Hvis man ikke direkte fortav de ubehagelige sider, dæmoniserede man dem. I John T. Lauridsens bibliografi handler langt størstedelen om modstand af den ene eller anden art, mens passivitet, samarbejde eller tyskvenlighed udgør en meget lille del. I den populære formidling blev nazismen, både den tyske og den danske, f.eks. anskuet som et resultat af enkelte menneskers fanatisme eller psykopati og ikke som en ideologi og et politisk system. Hertil kom, at det blev besættelsestidens sidste halvandet år og især de sidste 10 måneder fra folkestrejken i juli 44 til 5. maj 45, der kom til at danne model for det samlede billede af de fem år.

I et makroperspektiv kan man se samme form for mytologisering som hos Hæstrup og mange andre over hele Europa efter 1945, som det f.eks. blev vist på den store udstilling i Berlin med titlen "Mythen der Nationen. 1945" fra 2004 til 2005. Indtil 1970'erne og på visse områder senere var der ikke noget behov for at sætte spørgsmålstegn ved myterne. For i sidste ende havde det noget med befolkningernes behov at gøre, mytens levedygtighed som fortælling siger nemlig mere om brugernes behov end om sandhedsværdien. Som Roland Barthes siger i sin bog Mytologier: "Menneskene forholder sig ikke til myten i overensstemmelse med en sandhed, men med et behov; de afpolitiserer efter hvad de har brug for". ${ }^{4}$

En egentlig anfægtethed var derfor også så godt som fraværende i den danske faglitterære formidling af besættelsestiden, hvilket begynder at ændre sig fra slutningen af 1970'erne.

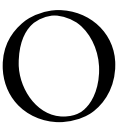
g nu tager vi fat på den konkrete forskning, som jeg vil inddele i et før og efter midten af 1990'erne. Fra det tidspunkt sker der nemlig en markant nyorientering.

Den egentlige forskning i besættelsestiden begynder med Jørgen $\mathrm{Hx}$ strups forskning - for han var jo langt fra kun propagandist. I 1954 udgav han bogen Kontakt med England og fem år efter Hemmelig Alliance i to bind. De er pionerværker, selvom de hovedsagelig skildrer modstandsbevægelsen og ikke i større omfang forhandlings- og samarbejdspolitikken. Den var jo også blevet fyldigt beskrevet i det, jeg vil kalde for den politiske legitimeringslitteratur, der udkom i årene umiddelbart efter besættelsen, bl.a. skrevet af partierne selv i store samleværker. Det er i høj grad Hæstrups fortjeneste at have påbegyndt og for en stor del indsamlet og bearbejdet kildemateriale om modstandsbevægelsen på et tidligt tidspunkt, som sikkert ellers ofte ville være forsvundet. Mange beretninger fra ledende personligheder i modstandskampen, der i dag ligger i Rigsarkivet - i alt ca. 80 arkiver og arkivfragmenter - skyldes således Hæstrups utrættelige indsats. Hans historiesyn er præget af tankerne om personerne som de drivende kræfter, og den udartning af samarbejdspolitikken, han mener fandt sted, tilskrives i høj grad en enkelt politiker, nemlig udenrigs- og senere statsminister Erik Scavenius. Her 
er tale om en reproduktion af modstandsbevægelsens opfattelse under besættelsen.

Også modstandsbevægelsens opståen tillægges enkeltmænds ønsker og handlinger. Det er den individuelle, personlige beslutning, der fører folk - eller mændene, for Hæstrups fremstilling er fuldstændig mandscentreret og modstandsbegrebet kun knyttet til mandlige handlinger - ind i modstandsbevægelsen, som så efterhånden - som summen af alle disse enkelthandlinger - vokser sig stor og bliver til en bevægelse, der kæmper kollektivt. Der er altså videnskabsteoretisk tale om det, man med et fint begreb kalder for metodologisk individualisme i modsætning til metodologisk kollektivisme, som kommunistiske og ny-marxistiske historikere har været fortalere for. De sidste har dog ikke sat noget varigt præg på forskningen.

I 1970'erne kom Hæstrups og enkelte andres værker til at stå for den såkaldte konsensuslinje inden for besættelsesforskningen. Her overfor stillede især Hans Kirchhoff en konfliktlinje.

Kirchhoffs og andre ledende besættelseshistorikeres forskning skete inden for rammerne af Udgiverselskabet til Danmarks nyeste historie, forkortet til DNH. Selskabet blev dannet i 1960-61 og var fra begyndelsen del af en politisk sammenhæng. I dag kender vi ordet historiepolitik, som vistnok blev dannet af Jürgen Habermas under den store vesttyske historikerstrid 1987-88. Det var det, politikerne ønskede selskabet skulle varetage på baggrund af den offentlige uro, der opstod på dette tidspunkt, forårsaget af Hjalf-sagen om den såkaldt skæve våbenfordeling. ${ }^{5}$

Politikernes bindeled til selskabet var undervisningsminister Jørgen Jørgensen, der ifølge Bo Lidegaard i Gads Leksikon Hvem var hvem 1940-45 var "blandt samarbejdspolitikkens støtter ... og så med dyb skepsis på den væbnede modstandskamp". Jørgen Jørgensens eksplicit udtalte ønske var, at der nu var forsket nok i modstandsbevægelsen; fremover skulle også den politiske, den folkelige, økonomiske og kulturelle side af sagen tages op. Der skulle altså foretages en 'afbalancering' af den efter politikernes mening ensidige interesse for rivalen fra besættelsesårene: modstandsbevægelsen. Forbindelsen mellem politik og videnskab - og videnskabens afhængighed af politikken eller staten, der jo sammen med Carlsbergfondet skulle finansiere hele herligheden - er altså ganske klar i denne sammenhæng. Men det er også klart, at politikerne hverken kunne eller ville detailstyre forskningen, hvis integritet iøvrigt blev sikret ved ansættelsen af - foruden Hæstrup selv, der nu skulle skrive om departementschefstyret (altså for så vidt om samarbejdspolitikken) - en række unge historikere, der fremover skulle komme til at tegne besættelsesforskningen, nemlig Henrik S. Nissen, Hans Kirch hoff og Henning Poulsen. Aage Trommer, der er den fjerde i kvartetten af store besættelseshistorikere, var ikke direkte knyttet til selskabet.

Meningen var jo, at udforskningen af besættelsestiden skulle tages mere systematisk op, således at den kom til at dække områder, der ikke hidtil var forsket i. DNH udsendte 10-11 værker, herunder 6-7 doktorafhandlinger, over de 30 år selskabet eksisterede. De kildemæssige forhold var i orden, idet forskerne fik privilegeret adgang til arkiverne - et privilegium, der ikke blev udstrakt til andre, heller ikke efter projektets afslutning - så principielt var vejen banet for en 
mere systematisk afdækning af det danske samfund under besættelsen. Men man kan ikke sige, at selskabet udnyttede disse betingelser optimalt. Værkerne var som oftest grundige og dybtgående monografier - bl.a. fremkom sent i forløbet Hans Kirchhoffs store værk om Augustoprøret 1943, der på mange måder blev banebrydende ligesom Ditlev Tamms bog om retsopgøret - men helhedsindtrykket er, at projektet blev styret ikke af en forskningsledelse, men af forskningspræferencerne hos den enkelte forsker.

Bøgerne omhandler vidt forskellige perioder, begivenheder og problemer i besættelsestidens historie. Forhandlingsog samarbejdspolitikken var det mest behandlede emne, i tråd med det oprindelige politiske ønske, men der var ikke tale om en planmæssig analyse af den, hverken kronologisk eller tematisk. Således blev årene 1941 og 42, hvor denne politik stod sin afgørende prøve, og hvor det, vi i dag ser som det mest belastende ved den fandt sted, slet ikke taget op. Kontroversielle forhold som kommunisternes internering, selve kommunistloven, tysklandsarbejderne, den politiske accept af værnemagtsarbejderne og af Frikorps Danmark, østrumudvalget, myndighedernes holdning til den tidlige illegale virksomhed og meget mere blev ikke inddraget. Bortset fra et enkelt værk blev heller ikke sociale og økonomiske forhold taget op. Og mangellisten kan fortsættes: DKP, der spillede så afgørende en rolle fra 1941 til 43, blev kun behandlet i Kirchhoffs værk, Frikorps Danmark og andre SS-frivillige samt Frihedsrådet (undskyld sammenstillingen!) var stort set ubehandlede; ejheller partiet Dansk Samling, de mere konservative kredse i modstandsbevægelsen eller de ikke-nazistiske, anti-parlamentariske

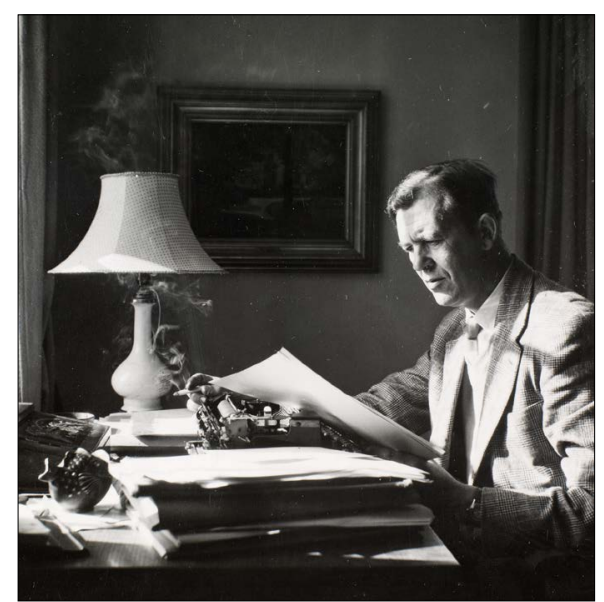

Historikeren, der blev modstandsmand-eller omvendt. Jorgen Hestrup (1909-1998) grundlagde forskningen $i$ besattelsestiden herhjemme. Her afbildet i studerekammeret hjemme i Skt. Klemens på Fyn omkring 1950 (foto: Det Kongelige Bibliotek, Kort-og Billedsamlingen).

grupper såsom Danmarks- eller Højgaardkredsen blev der plads til. Et så centralt emne som den tyske besættelsespolitik, der jo var forudsætningen for den særstilling, Danmark indtog blandt de besatte lande under krigen, ejheller. Kulturelle forhold og hverdagshistorie var selvsagt heller ikke med.

Ud fra de dybtgående, men spredte bidrag inden for DNH-projektet var det naturligvis ikke muligt at skrive en syntetiserende fremstilling.

Én væsentlig betydning fik DNHs forskning dog, og hvis politikerne havde $ø$ nsket sig et skønmaleri, fik de det ikke. Ikke mindst blev den kontrære forskning, som Hans Kirchhoff og Aage Trommer udviklede, en dagsordensætter for et par årtiers videre historieforskning.

Uden for selskabets regi undersøgte Aage Trommer antagelsen om den brede 
nationale kamp, som Hæstrup havde plæderet for, og nåede i værket Modstandsarbejde i narbillede fra 1973 frem til, at modstandsbevægelsen udsprang og domineredes af politiske miljøer på hhv. højrefløjen, f.eks. Dansk Samling og KU, og på venstrefløjen, hvor især DKP var betydningsfuld. Og i sin disputats om jernbanesabotagen fra 1971 påviste han med DSBs togtabeller som hovedkilde minutiøst, at den vidt udbredte forestilling om den danske jernbanesabotages store militære betydning for den allierede krigsførelse var en myte. Af de i alt 30 tyske divisioner, som fra sommeren 1944 blev transporteret fra Norge eller Danmark mod fronterne i syd, blev kun fem forsinket i et døgn eller mere, resten mindre eller slet ikke. Bogen var som nævnt Trommers doktorafhandling, og den vakte et ramaskrig i offentligheden, som Anette Warring og jeg har skildret det i bogen Besattelsestiden som kollektiv erindring. ${ }^{6}$ Trommer havde bandet i en kirke, hvor mange modstandsfolk og deres familier jo stadig kom, og det fik han i høj $\operatorname{grad}$ at føle.

Hans Kirchhoffs Augustoproret I-III fra 1979 repræsenterede et brud med metoden og begrebsapparatet i de fleste af DNH-værkerne. Hvor de fleste af disse, i reglen implicit, videreførte synsvinklen fra den politiske legitimeringslitteratur fra tiden kort efter befrielsen i deres syn på forhandlings- og samarbejdspolitikken, forholdt Kirchhoff sig langt mere kritisk-problematiserende hertil. Han anvendte begrebet kollaboration på samarbejdspolitikken - som han nøjedes med at kalde den, altså med undladelse af 'forhandlings'- idet han så kollaboration som en modsætning til modstand. Dette svarer også til den internationale termino- logi. I skarp modsætning til eksempelvis Hæstrups forskning om departementschefstyret understregede Kirchhoff også, at begrebet 'passiv modstand', som politikerne talte om efter krigen, "vil slette grænserne mellem kollaborationen og modstanden, ja overhovedet gøre begreberne meningsløse som andet end en skillemur mellem forræderne og så "os andre"? Samtidig var han af den opfattelse, at kollaborationen ikke afgørende blev brudt d. 29. august 43. "Med undtagelsestilstanden og Scavenius-regeringens tilbagetræden ophørte samarbejdspolitikken som et handlingsprogram under politisk ansvar, men kollaborationen fortsattes af statsorganerne, og gennem dem af politikerne "under jorden" - om end nu i et vist omfang som komplementærbegreb til modstanden. ${ }^{8}$ Det var den folkelige opstand i provinsbyerne i august 1943 , der væltede regeringen, og i modsætning til deres senere udsagn skete det meget imod politikernes vilje.

Ifølge Kirchhoff var der tale om to fundamentalt forskellige reaktionsmønstre på besættelsessituationen. Deraf navnet konfliktlinjen. Kollaborationen eller samarbejdet var ikke en neutral forhandlingsmekanisme til beskyttelse af de nationale danske interesser, som det normalt blev fremstillet, men et redskab til at sikre det politiske systems overlevelse.

Kirchhoffs konfliktsyn medførte angreb fra nogle, der foretrak den tidligere skelnen mellem begreberne egentligt samarbejde, altså kollaboration med fjenden, og så forhandlingspolitik. I øvrigt et begreb, der var dannet af Erik Scavenius i hans forsvarsskrift fra 1948 , Forhandlingspolitikken under besattelsen. Et af de stærkeste modangreb kom fra politisk side, hvor Folketingets formand, 
fhv. undervisnings- og udenrigsminister K.B. Andersen, ved disputatsforsvaret $e x$ auditorio og også senere udsatte den for et rasende (mod)angreb. Men det må man også læse om i Anette Warrings og min bog.

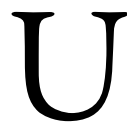
nder alle omstændigheder ændrede både Kirchhoffs og Trommers bøger diskursen om besættelsestiden. Nogle myter blev nedbrudt - hvor vidt dette så nåede ud i almenheden er et andet spørgsmål; foreløbig var det nok mest bundet til det historievidenskabelige miljø. En egentlig revision med tilhørende lidenskabelige - og videnskabelige - debatter, som man f.eks. oplevede i Vesttyskland under 'Historikerstreit' i 1986-87, har der ikke været tale om i Danmark. Det nærmeste vi er kommet er nok den lange og følelsesprægede debat om TV-serien Jane Horney 1985-86 eller den tilsvarende, men endnu mere absurde debat om Elle-Mie Ejdrup Hansens lysinstallation Linien-Lyset ved befrielsesjubilæet i 1995. De var begge, lige som så mange andre debatter, karakteriseret ved gamle modstandsfolks kamp imod initiativer til at kaste nyt lys over besættelsestiden. ${ }^{9}$

At vi ikke har haft den store politiskvidenskabelige debat er selvfølgelig forståligt, da hverken den politiske eller den historiografiske situation direkte kan sammenlignes med Tysklands. Men selv jævnført med Norge har der været meget lidt sprængstof i den danske debat. Det paradigmeskift i tilgangen til besættelsestiden, der er sket herhjemme i de sidste ca. 15 år med inddragelse af forskning $i$ minoriteter, dem på den forkerte side osv., skete allerede i Norge i 1980'erne i kraft af forskere som Hans Fredrik Dahl, Øystein Sørensen og Niels Johan Ringdal. ${ }^{10}$
Men i 1990'erne sker der alligevel ligesom en åbning af forskningen herhjemme, eller man kan måske tale om en videreudvikling af det delvise brud $\mathrm{i}$ forskningen, der skete med konfliktlinjens indtog. En ny forskergeneration - den tredje - begyndte at gøre sig gældende, og et paradigmeskift begyndte at tegne sig. Det gav sig udtryk i, at hidtil undertrykte eller glemte sider af besættelseshistorien blev taget op. Nogle af de første værker af den art var Anette Warrings bog Tyskerpiger - under besettelse og retsopgør fra 1994 og Rasmus Kreth og Michael Mogensens Flugten til Sverige. Aktionen mod de danske jøder, der kom året efter. Et slags program for denne type forskning blev formuleret i Warrings bog. På grundlag af Jürgen Habermas' bidrag til den tyske Historikerstreit inddrog hun moralske og etiske refleksioner over historikerens eget ståsted, dvs. de overvejelser, der ligger bag afvejningen mellem det analyserende, det forstående og det dømmende i relation til et kontroversielt historisk emne. I modsætning til den mere nationalt og $\mathrm{i}$ nogle henseender nationalistiske historieskrivning ville hun gerne finde en varsom balance og differentiering mellem det forstående og det dømmende. Og hun formåede at leve op til dette program, for hendes bog om tyskerpigerne var meget engageret, samtidig med at den bevarede overblikket over og distancen til sit emne. Alle synsvinkler på tyskerpigerne og opgøret med dem blev repræsenteret. Men det ville have været spændende at se de moralske og etiske aspekter endnu stærkere markeret, hvilket kun ville have kunnet gøres ved at udskille tyskerpigerne fra den politiske histories kategoriseringer i hhv. modstand og kollaboration. Warring henregnede således kvindernes seksuelle 
forhold til tyskere under kollaboration, men det er jo et spørgsmål, om det giver nogen mening at rubricere handlinger som politiske, der ikke blev opfattet som sådan af subjekterne selv. Noget andet er, at omverdenen opfattede det på denne måde, og at der blev knyttet en mentalitetsmæssig forbindelse mellem forestillingen om nationens skæbne og kvinders troskab, en forbindelse, som samtidig indebar, at tyskerpigernes handlinger blev opfattet som angreb på kønsbestemte normer for respektabel seksuel adfærd.

Warrings arbejde mødte ingen særlige indvendinger i offentligheden, måske fordi hendes accept af den almindelige historieskrivnings formelle opdeling af besættelsestiden såvel som de almene normer om rigtigt og forkert i perioden beskyttede mod kritik af hendes direkte og indirekte kritik af modstandsbevægelsen, der ofte tilskyndede til klipning af og andre overgreb mod pigerne, og af domstolene, der efter krigen bar over med overfaldsmændene.

En anden anonym gruppe som Tysklandsarbejderne blev taget op af Therkel Stræde i flere mindre skrifter. Og også John T. Lauridsen førte med sine studier i dansk nazisme et alternativt emne på banen. De var og er - der er jo kommet mange flere værker siden - præget af distance og nøgternhed - ikke blot i behandlingen af nazisterne, som altså ikke længere bliver dæmoniseret, men mere eller mindre bliver søgt forstået på deres egne betingelser - men også præget af distance og nøgternhed i forhold til samarbejdspolitik og modstandsbevægelse. Sammen med Henning Poulsens klassiske værk i DNH-regi om Besattelsesmagten og de danske nazister fra 1970 er en lakune hermed blevet lukket. Vi er blevet klogere, og det må jo være meningen med historieskrivning. Man kan også sige, at moraliseren er blevet erstattet af historisering, selvom man ikke kan komme udenom, at moral og historie ikke helt kan adskilles det vil jeg komme ind på lidt senere.

Med bidrag som disse fra 1990'erne var der tilsyneladende åbnet for en Pandoras æske.

$\mathrm{I}$ en tidsskriftartikel fra 1996 opstillede jeg spørgsmålet, om besættelseshistorien var på vej mod tomhed eller et nyt paradigme. ${ }^{11}$ Det er nu besvaret med, at det blev det sidste.

I overgangsfasen var forskningens præmisser, værdier og relevans blevet omeller nydefineret, og med de værker, som nærmest væltede frem i 00'erne, blev det også muligt at skrive nye synteser, som jeg ligeledes skal vende tilbage til.

3. generationshistorikerne har siden præget forskningen stærkt, og det er ikke gået ubemærket hen i offentligheden. Tværtimod er flere af deres værker enten blevet bestsellere, har været med til at sætte den politiske dagsorden eller har på anden måde vakt opsigt.

Jeg har optalt tolv områder, hvor der inden for nogle få år er kommet væsentlig ny forskning:

- Det økonomiske samarbejde med og tilpasning til Tyskland

- Partiernes historie under besættelsen ${ }^{12}$

- Modstandsbevægelsen, især sabotage og stikkerlikvideringer ${ }^{13}$

- Den tyske besættelsespolitik

- Dansk nazisme og andre tabere og marginaliserede grupper ${ }^{14}$

- Retsopgøret og de dømtes senere skæbne ${ }^{15}$

- De tyske flygtninge 
- Jøderne og jødeaktionen i 1943 samt dansk antisemitisme ${ }^{16}$

- Folkestemningen

- Den sorte børs ${ }^{17}$

- Biografier ${ }^{18}$

- Besættelseshistoriografien ${ }^{19}$

De i noterne nævnte værker er eksempler på nogle af vægtigste værker.

Desuden er der udkommet to leksika om besættelsestiden og fire synteser. Så der er tale om en rig høst på nogle få år.

Og så har jeg ikke medregnet de mange utrykte historiespecialer, som er skrevet på universiteterne. Uden specialerne drejer det sig om mindst 80 værker, når man regner længere tidsskriftsartikler med.

Det siger sig selv, at det ikke er muligt at omtale alle disse værker, derfor har jeg udvalgt bidragene på fire af de nævnte områder, som jeg vil sige lidt mere om. I udvælgelsen har jeg skelet til det, man med et godt dansk ord kalder for public history, dvs. til, om de enkelte værker eller grupper af værker har været diskuteret i en større offentlighed end den, der knytter sig til videnskabsfaget historie.

I 2007 udkom et værk, som jeg finder vigtigt, og som brød med den ret ensidige fokusering på den politiske historie og nærmede sig mentalitetshistorien. Det var Palle Roslyng-Jensens Danskerne og besattelsen. Holdninger og meninger 19391945. Der har jo i mange år hersket usikkerhed om, hvordan den danske befolkning som sådan forholdt sig til den tyske besættelse. Yderpunkterne har på den ene side været påstanden om alle danskes tilslutning til modstand fra begyndelsen og på den anden andres påstand om, at befolkningen må ses som et stort bundt værnemagere, der ivrigt handlede med og producerede for tyskerne og ikke interesserede sig for andet. Det er ikke denne økonomiske side, Roslyng-Jensen beskæftiger dig med, men den opinionsmæssige, og ud fra ca. 70 dagbøger og et større rapportmateriale, bl.a. af tysk proveniens, følger han udviklingen i folkets holdning til og meninger om besættelsen, nazismen, krigens udvikling mm. Dagbøgerne er ikke særlig repræsentative for befolkningssammensætningen, det er nærmest den bymæssige middelklasse, der kommer til orde, men alt i alt virker analysen af deres ytringer alligevel overbevisende på et mere generelt plan. Hovedkonklusionen er, at "den nationale og patriotiske holdning, som var udbredt og som kendetegnede opfattelsen af besættelsestiden i de første 25 år efter befrielsen - [det skal måske snarere være 40 eller 50 år, c.b.] - blev først fuldt etableret i de sidste måneder inden befrielsen". ${ }^{20}$

'Den kolde skulder' og 'passiv modstand' blev jo det billede, der senere fæstnede sig af danskernes indstilling til besættelsesmagten fra et tidligt tidspunkt. At det skulle have været tilfældet dementeres klart af dagbøgerne og det øvrige materiale. Men det betød ikke, at befolkningens majoritet ikke allerede tidligt var engelskvenlig og anti-tysk, selvom opinionen svingede noget, især i sommeren 1940, hvor Tyskland efter Frankrigs fald virkede uovervindeligt.

Mange havde også svært ved at finde ud af, om de skulle støtte Tyskland eller Sovjetunionen eller forholde sig neutrale, da Tyskland gik til angreb på Sovjet i sommeren 1941. Og det var først fra 1943, at en fast tro på en allieret sejr for alvor manifesterede sig. Roslyng påviser også en differentiering $i$ holdninger alt efter om det drejede sig om større byer 
eller landet - derude var indstillingen over for tyskerne ikke så negativ, hvilket selvfølgelig bl.a. hang sammen med de materielle fordele, landbruget havde gennem eksporten til Tyskland. Hvad angår spørgsmålet om modstand fra den første dag var der så at sige ingen opslutning, mens holdningen til modstandsbevægelsen blev stadig mere positiv fra 1943 og frem. Som en af dagbogsskriverne skrev. "For unge med oprørstrang var besættelsesmagten den ultimative autoritære faderskikkelse". 21

Palle Roslyngs bog vakte ikke nogen debat af betydning, hvilket måske kan have en sammenhæng med bogens ret læseruvenlige lay out med en meget lille og tæt sat skrift.

Opsigt vakte derimod de værker, der udkom om Danmarks økonomiske tilpasning til 'Neuropa', jeg tænker her på de tre Berlingske-journalisters bog Krigens kabmand - det hemmelige opgor med Riffelsyndikatet, A.P. Moller, Novo og den ovrige storindustri efter Anden Verdenskrig, 2002, Steen Andersens Danmark i det tyske Storrum og De gjorde Danmark storre om entrepenørerne fra hhv. 2003 og 2005 samt Joachim Lunds Hitlers spisekammer. Danmark og den europiiske nyordning 1940-43, også fra 2005, samt to tidligere artikler fra hans hånd. ${ }^{22}$ Nævnes skal også Mogens Rostgård Nissens Til falles bedste - det danske landbrug under besattelsen fra samme år, der ligesom hører med i den pludselige oversvømmelse med værker om den økonomiske tilpasning. Nissen konkluderede, at de danske leverancer af landbrugsvarer spillede en væsentlig rolle for Tyskland under krigen og jo større rolle jo længere krigen varede. ${ }^{23}$ Eksporten spillede ligeledes ind på den (moderate) tyske besættelsespolitik i Danmark, idet tyskerne lagde stor vægt på den danske 'Lieferfreude'.

Også Ole Brandenborg Jensen har udgivet en bog om de økonomiske forhold under besættelsen, betitlet Besattelsestidens økonomiske og erbvervsmassige forhold. Studier i de okonomiske relationer mellem Danmark og Tyskland 1940-1945, 2005. Han er uenig med Joachim Lund og Mogens R. Nissen i vurderingen af især landbrugseksportens betydning for den tyske befolkning og krigsførelse, idet han tillægger den mindre vægt. ${ }^{24}$ Hans konklusion med hensyn til de makro$ø$ konomiske virkninger af værnemagtens befæstningsarbejder er, at de må betragtes som Danmarks største bidrag til den tyske krigsførelse, og at de i princippet frigjorde et lignende antal tvangsarbejdere til indsættelse andre steder i det besatte Europa. Befæstningsarbejderne havde samme virkning som en keynesiansk ekspansiv politik i en situation med stor dansk ledighed. Ikke kun cementindustrien og entrepenørerne, men også mange danske arbejdere øgede deres indtjening markant. ${ }^{25}$

De nævnte bøger om den økonomiske tilpasning supplerer hinanden og har langt om længe givet os et overblik over denne vigtige side af besættelseshistorien.

Man kan som John T. Lauridsen i sin historiografiske oversigt som indledning til den store udgivelse af Werner Bests korrespondance tage afstand fra det, han kalder den moralske "forargelse over de omtalte virksomheders arbejde for og fortjeneste fra værnemagten" ${ }^{26}$ Eller som når Henning Poulsen et sted har skrevet, at "når forargelsen går ind, så går forstanden ud". Men dette spørgsmål kan ikke bare afhandles på nogle få linjer, som Lauridsen gør det, for det er jo et videnskabsteoretisk problem, der 
kendetegner al historieskrivning, ja vel egentlig al humanistisk forskning, og som jeg vil imødegå med, at moralsk stillingtagen er uundgåelig - det afgørende er, at forskeren lægger sine værdipræmisser frem, så læseren der ud fra kan tage stilling til det skrevne. Hvis vi ikke må være moralske, hvordan skal vi så bedømme Hitler og nazismen, for slet ikke at tale om Holocaust? For øvrigt tager Lauridsen også selv moralsk stilling, når han senere i samme indledning undrer sig over, at besættelsesmagtens danske håndlangere blev straffet hårdt - ofte med dødsstraf - mens, som han skriver, "deres tyske foresatte og ansvarlige nok senere blev straffet, men at Best kunne forlade Danmark 1951 og Pancke og Bovensiepen i 1953 som frie mænd? Og andre tyske forbrydere med dem, en del af dem blev hverken fundet eller straffet. Retsopgøret bar i sig selv næring til en senere generations moraliserende historieopfattelse". ${ }^{27}$ Men det er klart, at der altid må være tale om en balance mellem følelse og fornuft.

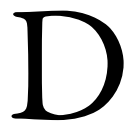
et var en ekskurs. Og moral eller ikke moral, så belyser de ovennævinte værker i hvert fald et hidtil mørkelagt område af besættelseshistorien. Også rent kildemæssigt, fordi det jo ikke tidligere var muligt at få adgang til de relevante arkiver, undtagen for DNH-historikerne. Og det var nok en af grundene til, at de nye bøger vakte offentlighedens interesse. Bogen om krigens købmænd, der byggede videre på artikler i Berlingske Tidende, førte til Mærsk McKinney-Møllers salg af sine aktier i samme avis og avisens overgang til en ny ejer, og Joachim Lunds undersøgelser til, at F.L. Smidth blev eksponeret for at have anvendt jødiske og roma-slavearbejdere på en fabrik i Estland under krigen som en del af den erhvervsmæssige fremtrængen i "østrummet", som det blev kaldt efter Tysklands angreb på Sovjet. Firmaet måtte for nogle år siden betale erstatning til de få overlevende jøder og romaer.

Med hensyn til planerne for "storrummet", som Danmark var tiltænkt en plads i som leverandør af landbrugsvarer, betoner Lund i øvrigt, at det tyske nazistiske polykrati hidtil har fyldt for lidt i udforskningen af det tysk-danske økonomiske forhold. Hans arbejder udmærker sig i høj grad ved at inddrage arkiverne i Tyskland, hvilket hidtil havde været en mangelvare.

Steen Andersens fortjeneste i hans første bog er at vise, hvordan planerne om $ø$ konomisk samarbejde via handelsmæssige aftaler opstod allerede før Scavenius trådte til d. 8. juli 1940, initieret af en gruppe ledende embedsmænd i Udenrigsministeriet - de såkaldte Tysklandseksperter - og at planerne ikke kun havde et økonomisk formål, men i lige så høj, eller endda i højere grad, et politisk. For Scavenius var den politiske tilnærmelse til Tyskland og ønsket om faste forhandlingskanaler det bærende motiv, og det er denne linje, som senere er blevet kaldt den 'aktivistiske', mens politikerne i Nimandsudvalget og delvis i regeringen stod for en mere afventende holdning, kaldet 'attentisme', altså at vente og se. For alle var forudsætningen for det dansk-tyske samarbejde dog, at det parlamentariske demokrati og de danske politiske institutioner skulle bevares. I bagklogskabens lys kan det virke naivt, men sådan var forestillingen.

Hvis man skal tro bestemte kilder, opflammede indholdet i Steen Andersens bog statsminister Anders Fogh Rasmussen så meget, at han holdt sin herostratisk 
berømte tale på 60 års dagen for bruddet med tyskerne d. 29. august 2003, hvor han i absolutte vendinger fordømte samarbejdspolitikken moralsk såvel som politisk. I kampen mellem demokrati og diktatur kunne man ikke forblive neutral, sagde han. Og det var Danmark jo heller ikke blevet, da det nogle måneder forinden var gået ind $\mathrm{i}$ en angrebskrig mod Irak som led i 'de villiges koalition'. Sådan kan man også bruge historien.

Steen Andersens anden bog, der også var hans ph.d.-afhandling, analyserede danske entrepenørvirksomheders aktivitet og politik fra 1919 til 1947, og også her blev det påvist, at erhvervslivet satte fortjeneste over nationale hensyn. Bogen fik stor bevågenhed i medierne, men er i Historisk Tidsskrift blevet kritiseret for mangelfuld eller ligefrem vildledende kildebrug. ${ }^{28}$

De nævnte værker om industriens og landbrugets forhold under besættelsen var i øvrigt også igangsat på politisk initiativ, hvor Enhedslisten efter afsløringerne i Berlingske Tidende og før regeringsskiftet i 2001 fik gennemført en bevilling til udforskning af besættelsestidens $ø$ konomiske og erhvervsmæssige historie, der blev lokaliseret på Center for virksomhedshistorie på CBS.

Hvad angår det område, jeg nævnte, om den tyske besættelsespolitik i Danmark, er der jo med Lauridsens udgivelse af Werner Bests korrespondance med Auswärtiges Amt, som udkom sidste efterår, taget et stort skridt mod en større forståelse af denne politik. Meget af den oprindelige korrespondance og andre dokumenter blev brændt af tyskerne før befrielsen, men det er alligevel lykkedes for John T. Lauridsen og Jakob K. Meile at samle et meget stort materiale, ikke mindst ved at gennemtrawle adskillige tyske arkiver. Det er en imponerende præstation.

Det interessante er her, at besættelsen bliver set ud fra en tysk optik, og udgiveren kan bekræfte, at Danmark var et særtilfælde for tysk besættelsespolitik i Europa. Forholdene i Danmark var fulde af paradokser, og han kan slutte sig til Henning Poulsens næsten surrealistiske beskrivelse fra 1995:

"I dansk besættelseshistorie er der mangt og meget, der er vanskeligt at forklare en polak eller blot en nordmand. Vi samarbejdede politisk med besættelsesmagten, fik først de bedste og frieste levevilkår i det besatte Europa, dernæst en modstandsbevægelse til halv pris og blev til slut allieret uden at komme i krig". ${ }^{29}$

I værket er alle tekster, også indledningen og kommentarerne, oversat til tysk, hvad der gør det brugbart i internationale sammenligninger. Aage Trommer og Henrik Lundtofte har desuden bidraget med oversigter over hhv. jernbanesabotager og tyske modterroraktioner mellem 1943 og 45.

Lundtofte har i øvrigt også kastet lys over det forhadte Gestapo i Danmark med en bog om samme fra 2003 - Gestapo! - hvor han påviser den relative moderation, Gestapo udviste her i forhold til i andre besatte lande. Det kom først til landet i efteråret 1943 efter regeringens afgang, og fra 1944 blev der anvendt tortur, men ikke generelle repressalier mod civilbefolkningen. Personificeret i Werner Best kunne den samarbejdspolitiske linje og de beherskede handlingsmønstre overleve, også under departementschefstyret, fordi Hitler trods utilfredshed, mistro og den manglende udførelse af sine terrorkrav hverken forflyttede Best eller 
forlangte en egentlig kursændring. "Resultatet var", som Lundtofte skriver, "at de civile ofre for den tyske terror i Danmark skal tælles i hundreder, ikke i tusinder eller i hundredtusinder",30 som det var tilfældet særlig i Østeuropa og Sovjetunionen. Baggrunden var den tyske interesse $i$ at opretholde landbrugsproduktionen samt at SS var relativt svagt i Danmark, samtidig med at Best trods kritik fra Hitler stadig var i stand til at fastholde sin relativt moderate linje, som han mente var i større overensstemmelse med tyske interesser end en radikal linje, som Terboven f.eks. var udtryk for i Norge.

Selvom både Lauridsens og Lundtoftes forskningsresultater må rubriceres under det, nogle kalder for revisionisme - et rigtigere ord ville nok være realisme - vakte de dog ikke den store debat, for nu at se påpublic history-apektet igen. Det gjorde derimod Kirsten Lylloffs forskning i de tyske flygtninge, der kom til Danmark $i$ krigens slutning. Det gav genlyd, da hun, der også er uddannet læge, i en artikel i det ellers ret støvede Historisk Tidsskrift i 1999 kunne påvise, at de danske sundhedsmyndigheder, lægeorganisationer og endda Dans Røde Kors i 1945 nægtede at behandle civile tyske flygtninge, med det resultat, at der ud af ca. 250.000 flygtninge i 1945 døde 13.492, hvoraf over 7.000 var børn under fem år. Ifølge Lylloff døde de fleste af i øvrigt let behandlelige sygdomme såsom mæslinger, mavekatar og dehydrering, og dødsfaldene skete både før og ikke mindst efter befrielsen. ${ }^{31}$

Lylloff blev som forventeligt mødt med indigneret modsigelse, både fra enkelte læger og fra nogle modstandsveteraner, men hendes tal og undersøgelse i det hele taget er i alt fald indtil videre ikke blevet tilbagevist. Forholdet chokerede mange, da dagbladet Politiken trykte en kronik af Lylloff, dels fordi en sådan mangel på humanitet strider stærkt imod nutidens udtalte idealer fra dansk side, dels fordi forholdet var blevet fortiet i så mange år. Administratorer og læger, der kendte sandheden eller i hvert fald en del af den, havde holdt den for sig selv i 54 år, og historikerne havde ikke vist nogen interesse for emnet. En historisk afhandling af Henrik Havrehed, der var blevet antaget som doktordisputats, havde ovenikøbet manipuleret med emnet uden at blive imødegået af dem, der antog den som disputats. ${ }^{32}$

$\mathrm{F}$ ør jeg konkluderer, vil jeg lige kort omtale de bredere værker, der er udkommet om besættelsestiden i nullerne. I mange år bestod der en kløft mellem den store offentlighed og historieforskningen omkring besættelsestiden. Det virkede, som om der manglede et led i 'formidlingskæden', et led imellem den bredere rettede sag- og skønlitteratur på den ene side, som frembragte værker som Scherfigs Frydenholm, Aalbæk Jensens Kridtstregen og Tage Skou-Hansens De nogne traer, og som opnåede høje læsertal, og så på den anden side den egentligt forskningsbaserede litteratur, der $i$ visse tilfælde som Aage Trommers, Hans Kirchhoffs og Ditlev Tamms har revideret forskningens opfattelse af besættelsestiden og retsopgøret betragteligt. Et af de få nyere værker, der efter min opfattelse etablerer et sådant mellemled, er Henrik S. Nissens udgivelse af brevvekslingen mellem Hal Koch og K.E. Løgstrup fra besættelsestiden, Kere Hal - Kere Koste, fra 1992. Her får læseren et indblik i såvel de politiske som de eksistentielle hovedkonflikter mellem to engagerede 
danske demokrater under besættelsen. Og samtidig er bogen levende og let læst.

Men ellers har det knebet med den brede formidling. Det er der dog også rådet bod på i de senere år. Det drejer sig dels om de to leksika, der er udgivet af Gads Forlag, ${ }^{33}$ og dels om to samlede fremstillinger, den ene skrevet af Bo Lidegaard under titlen Kampen om Danmark og den anden med titlen Danmark besat. Krig og hverdag 1940-45, skrevet af Claus Bundgård Christensen, Joachim Lund, Niels Wium Olesen og Jakob Sørensen. Begge bøger udkom omkring 65 års jubilæet for besættelsen eller 60 års jubilæet for befrielsen i 2005, hvad man nu vælger, et jubilæum, der i øvrigt blev celebreret under betydelig mere sobre former end de to foregående. Også Hans Kirchhoff og Henning Poulsen har udgivet samlede fremstillinger, ${ }^{34}$ men jeg holder mig her til leksikaene og de to bøger af 3 . generations besættelseshistorikerne.

Mærkeligt nok har samlede fremstillinger af besættelseshistorien som nævnt været en mangelvare - man skulle helt tilbage til 1968 for at finde den sidste samlede fremstilling, nemlig Børge Outzes Danmark under den anden verdenskrig, bd. 1-4, og til 1965 , hvis man ville finde en fremstilling, der var skrevet af forskere. Det var Besattelsens Hvem-Hvad-Hvor under Hæstrups og elevers redaktion, der var genudgivet mange gange senere under forskellige titler. Den negative tolkning af denne mangel er selvsagt, at besættelseshistorien befandt sig i et tomrum, hvor den var rådvild, fordi den manglede et værdigrundlag og et helhedssyn. Den rent nationale orientering blev mere og mere forældet, og nye generationers mindre nationalt og mere internationalt og universelt orienterede holdninger var endnu ikke slået rigtigt igennem.
Det skete så til gengæld med de to leksika og synteserne fra 2005. Leksikaene er hårdt tiltrængte opslagsbøger, hvor man kan få svar på en masse spørgsmål til besættelseshistorien, de er også mindre tendentiøse end Hvem-Hvad-Hvor og får alle grupper med. Men de udgør naturligvis ikke en syntese. Det gør derimod de to brede, men forskningsbaserede bøger af de yngre historikere. De er også præget af en ny generations syn.

Mens Bo Lidegaards bog er anlagt som politisk historie og ligger nærmere konsensus- end konfliktlinjen, men må siges at være ualmindelig velskrevet, udgør de fire andres i højere grad et forsøg på at nyrorientere den brede fremstilling indholdsmæssigt. Den fylder næsten tusinde sider og har, lige som Lidegaards iøvrigt, integreret krigens internationale dimension, men medtager i højere grad hverdagshistorien og de økonomisksociale forhold. Kort sagt indarbejder den de fleste af de senere års forskningsresultater. Desuden bryder den på linje med Lidegaard med konventionen om at se besættelsestiden som en parentes fra 1940 til 1945 , men ser den i forlængelse af 1930'ernes økonomiske og politiske problematik, lige som den har retsopgøret og kollektiverindringen med.

Når vi er ved den brede formidling, bør udstillingen Sparretid på Nationalmuseet i 2005 også nævnes. Der var tale om en bred hverdagshistorie, hvor besættelsestidens kriser og markante begivenheder også havde fået plads. Det store katalog, der var redigeret af Henrik Lundbak, anlagde en række utraditionelle indfaldsvinkler, og alt i alt var der tale om en meget veloplagt museumsformidling, der løftede sig over de gamle opdelinger. ${ }^{35}$ 
A fsluttende må det siges, at de fleste af de områder, som jeg i begyndelsen af foredraget opregnede som værende ikke-behandlede i besættelseslitteraturen, nu er blevet inkluderet, såvel i forskningen som i de bredere fremstillinger. Der er selvfølgelig stadig lakuner og egentlige gåder som f.eks. Werner Bests behandling af jødeaktionen i efteråret 1943, men det er svært at pege på områder, der slet ikke er blevet berørt af forskningen eller den litterære formidling. Og det er jo også blevet lettere at forske i besættelsestiden og retsopgøret, hvis der altså ikke lige kommer et par tyve på Rigsarkivet i vejen, eller hvis Frihedsmuseet ikke brænder.

Den enorme litteratur, som John T. Lauridsen for første gang lagde samlet frem i sin bibliografi i 2002, og som siden er blevet suppleret, har givet nutiden og fremtiden rige muligheder for at arbejde med litteraturen. Hertil kommer det store arkivalske materiale både fra besættelsen og retsopgøret, som efterhånden er blevet deklassificeret, samt nogle private forenings- og firmaarkiver, der kan bidrage til at belyse mange forhold langt mere indgående, end det tidligere er sket. - Lige i forbifarten: Da jeg selv søgte om arkivadgang i 1979, varede det elleve år, før jeg fik den, og jeg måtte først skrive en bog om mine prøvelser, før det langt om længe lykkedes. ${ }^{36}$ - Hertil kommer det glædelige, at danske besættelseshistorikere er begyndt at forske i udenlandske arkiver, især de tyske, hvor der også findes meget stof om Danmark.

Både forskning og formidling er i langt højere grad end tidligere præget af pluralisme samtidig med en vilje til at tænke i helheder. Så som svar på mit eget spørgsmål fra 1996, om forskningen ville ende i tomhed eller et nyt paradigme, kan man lykkeligvis konkludere, at det blev det sidste. I paradigmet indgår som nævnt helhedsorienteringen og også den internationale dimension. Forskningen er blevet mindre introvert og mere åben for ydre påvirkninger.

Også her er den på linje med den internationale udvikling, dog måske med et årtis forsinkelse. I sin indledning til det store museumskatalog over den udstilling i Berlin, jeg tidligere omtalte, skriver franskmanden Etienne Francois, der er professor i tysk historie i Berlin, i en komparativ oversigtsartikel:

"Den totale omvending af mindet om krig og folkemord i de neutrale lande er måske det bedste eksempel på en overgribende dynamik, hvis udvikling ikke er afsluttet. Efter de første kritiske spørgsmål i de sene 60'ere tiltager processen i 70 'erne og 80 'erne med at sætte spørgsmålstegn ved efterkrigskonsensussen for at nå sit højdepunkt i det sidste årti af det 20. århundrede. I hvert land fuldbyrdes denne forandring under den dobbelte indflydelse af initiativer inde- såvel som udefra. Den holdning, der blev indtaget af hvert land i krigsårene, bliver i stadig mindre grad vurderet ud fra et nationalt interessesynspunkt og stadig mere under hensyntagen til universelle, etisk-politiske kriterier såsom menneskerettigheder, tolerance og demokrati. Den offentligt fremførte og lidenskabeligt diskuterede kritik koncentrerer sig om to aspekter: på den ene side den moralske tvetydighed i de erhvervsmæssige forbindelser med Nazi-Tyskland og på den anden side flygtningepolitikken, der ses som restriktiv. I stedet for billedet af forsvarsberedte, neutrale og barmhjertige nationer sætter billedet af eftergivende og 'grusomme' 
lande sig igennem, som står under direkte eller indirekte mistanke for involvering $\mathrm{i}$ folkemordet". ${ }^{37}$

Om en generation eller to vil der måske opstå et nyt paradigme, men her i 2013

\section{Noter}

1 John T. Lauridsen: Samarbejde og modstand. Danmark under den tyske besattelse 1940-45. En bibliografi, Det Kongelige Bibliotek/Museum Tusculanums Forlag. 2002, s. 15.

2 Jf. Anette Warring: En fest for demokrati og folkefællesskab - om 40-års jubilæet for Danmarks befrielse. Claus Ladegaard (red.): Når medierne spinder historiens tråd. 1993.

3 Claus Bryld og Anette Warring: Besattelsestiden som kollektiv erindring. Historie- og traditionsforvaltning af krig og besattelse 1945-1997. 1998, s. 58-61.

4 Roland Barthes: Mytologier. 1996 (1957), s. 270.

5 Jf. Claus Bryld: Historie og offentlighed. Kampen om arkivadgang i Danmark 19711982. 1983, s. 86-105.

6 Jf. Bryld og Warring: Op. cit, s. 387ff.

7 Hans Kirchhoff: Augustoproret 1943. Samarbejdspolitikkens fald. III., s. 86.

8 Ibid. I, s. 12.

9 Jf. Bryld og Warring: Op. cit, s. 226-244.

10 Ibid. s. $379 \mathrm{f}$.

11 Claus Bryld: Besættelseshistorien - på vej mod tomhed eller et nyt paradigme? Den jyske Historiker 75-76, 1997.

12 Henrik Lundbak: Staten sterk og folket frit. Dansk Samling mellem fascisme og modstandskamp 1936-47. 2001; Joacim Lund (red.): Partier under pres - demokratiet under besattelsen. 2003. kan vi foreløbig konstatere, at de to spørgsmål, Aage Trommer stillede i en lille antologi fra 1995, nemlig "Hvad har vi nået, og hvad mangler vi?", kan besvares med et for første dels vedkommende "meget" og for anden dels et "ikke så meget".

13 Jf. bl.a. Esben Kjeldbæk: Sabotageorganisationen BOPA 1942-1945. 1997; Knud J.V. Jespersen: Med hjalp fra England. Special Operations Executive og den danske modstandskamp 1940-1945, I-II. 2000; Peter Birkelund: De loyale oprorere. Den nationalt-borgerlige modstandsbevagelses opståen og udvikling 1940-45. 2000; Samme: Holger Danske. Sabotage og likvidering 1943-45, I-II. 2008; Henrik Lundbak: Staten sterk og folket frit. Dansk Samling mellem fascisme og modstandskamp 193647. 2001; Stefan Emkjær: Stikkerdrab. 2000. Peter Øvig Knudsen: Efter drabet.

Beretninger om modstandskampens likvideringer. 2001;

14 Jf. bl.a. Claus Bundgård Christensen, Niels Bo Poulsen og Peter Scharff Smith: Under hagekors og Dannebrog. Danskere i Waffen SS 1940-45. 1998; Andreas MonradPetersen: Schalburgkorpset - historien om korpset og dets medlemmer. 2000; John T. Lauridsen: Dansk nazisme 1930-45 - og derefter. 2002; Samme: "Foreren har ordet!" Frits Clausen om sig selv og DNSAP. 2003; Mikkel Kirkebæk: Beredt for Danmark. Nationalsocialistisk ungdom 1932-1945. 2004.

15 Jesper Nissen: Den strengeste straf. Dødsstraffens genindforelse i Danmark 1945. 2001. Søren Billeschou Christiansen og Rasmus Hyllested: På den forkerte side. De danske landssvigere efter befrielsen. 2011. 
16 Jf. bl.a. Lone Rünitz: Danmark og de jødiskeflygtninge 1933-1940. 2000; Sofie Lene Bak: Jodeaktionen oktober 1943. 2001; Samme: Dansk antisemitisme 1930-1945. 2004; Hans Sode-Madsen: Dramaet om de danske joder 1933-1945. 2003; Hans Kirchhoff og Lone Rünitz: Udsendt til Tyskland. Dansk flygtningepolitik under besattelsen. 2007.

17 Claus Bundgård Christensen: Den sorte bors - fra besattelsen til efterkrigstid. 2003.

18 Jf. bl.a. Wilhelm Christmas-Møller: Christmas-Moller og det konservative Folkeparti, I-II. 1993; Mogens Rüdiger: Uden tvivl. Erling Foss 1897-1982. 2000. Hans Bonde: Niels Bukh. En politisk-ideologisk biografi, I-II. 2001; Niels Barfoed: I unáde. Peter P. Rohde og opgøret med kommunismen. 2001; Samme: En kriger. Portret af Ole Lippmann. 2005; Ole Ravn: Forer uden folk. Frits Clausen og Danmarks National Socialistiske Arbejder-Parti. 2007. Mikkel Kirkebæk: Schalburg - en patriotisk landsforreder. 2008. Morten Møller: Mogens Fog. Fra modstandshelt til landsforreder, I-II. 2009. Samme: Hvem er Nielsen? En fortalling om kommunisten og modstandsmanden Børge Houmann. 2012. Jes Fabricius Møller: Hal Koch. En biografi. 2009. Morten Thing: Sabotoren. Min fars historie. 2011.

19 Claus Bryld og Anette Warring: Besattelsestiden som kollektiv erindring. Historie- og traditionsforvaltning af krig og besattelse 1945-1997. 1998, s. 343-414. Palle Roslyng-Jensen: Besættelsesforskningen 1995-2001. En national eller en ideologisk historieskrivning? Historisk Tidsskrift, 101:2. 2001. Samme: Besættelseslitteraturen 2001-2006. Postmodernistisk variation og fortsat hausse. Historisk Tidsskrift 106:1. 2006. John T. Lauridsen: Tysk besættelsespolitik i Danmark - en forskningsoversigt. Werner Bests korrespondance med Auswärtiges Amt og andre tyske akter vedrorende besattelsen af Danmark 19421945, I. 2012, s. 58-165.
20 Palle Roslyng-Jensen: Danskerne og besattelsen. Holdninger og meninger 1939-1945. 2007. s. 320.

21 Ibid. s. 169.

22 Joachim Lund: Den danske østindsats 1941-43. Historisk Tidsskrift 95:1, 1995. Lebensraum og kollaboration 1941-43. Den jyske Historiker 71, 1995.

23 Jf. også Palle Roslyng-Jensen: Besættelseslitteraturen 2001-2006. Postmodernistisk variation og fortsat hausse. Historisk Tisskrift 106:1. 2006, s. 219-23.

24 Jf. diskussionen mellem de tre i hhv. Historisk Tidsskrift 108:1, og 108:2.2008.

25 Roslyng-Jensen, jf. note 21.

26 John T. Lauridsen: Op. cit. I, s. 61.

27 Ibid. s. 131.

28 Finn Østrup: De gjorde Danmark større. Hvad siger kilderne? Historisk Tidsskrift 109:2, 2009. Steen Andersen: For firmaets ære. Svar til Finn Østrup. Ibid.

29 John T. Lauridsen: Op. cit. s. 164, efter Henning Poulsen: Dansk modstand og tysk politik. Den jyske Historiker 71, 1995 , s. 17.

30 Henrik Lundtofte: Gestapo! Tysk politi og terror i Danmark 1940-45, 2003, s. $218 f$.

31 Kirsten Lylloff: Kan lægeløftet gradbøjes? Dødsfald blandt og lægehjælp til de tyske flygtninge i Danmark 1945. Historisk Tidsskrift, 99:1.

32 Henrik Havrehed: De tyske flygtninge $i$ Danmark 1945-1949. 1987.

33 Gads leksikon om dansk besattelsestid 19401945 under redaktion af Hans Kirchhoff, John T. Lauridsen og Aage Trommer. 2002, og Gads leksikon Hvem var hvem 1940-1945.2005, under samme redaktion.

34 Hans Kirchhoff: Samarbejde og modstand under besattelsen. En politisk historie. 2001, Henning Poulsen: Besattelsesårene 1940-45. 2002.

35 Jf. omtalen i Palle Roslyng-Jensen: Besættelseslitteraturen 2001-2006. Postmodernistisk variation og fortsat hausse. Historisk Tidsskrift 106:1, 2006, s. $208 \mathrm{f}$. 
36 Claus Bryld: Historie og offentlighed. Kampen om arkivadgang i Danmark 1971-82. 1983.

37 Etienne Francois: Meistererzählungen und Dammbrüche: Die Erinnerung an den zweiten Weltkrieg zwischen Nationalisierung und Universalisierung. Monika Flacke (red.): Mythen der Nationen. 1945 - Arena der Erinnerungen I, 2005. 